\title{
Variability of three-dimensional sea breeze structure in southern France: observations and evaluation of empirical scaling laws
}

\author{
P. Drobinski ${ }^{1}$, S. Bastin ${ }^{1}$, A. Dabas ${ }^{2}$, P. Delville ${ }^{3}$, and O. Reitebuch ${ }^{4}$ \\ ${ }^{1}$ Institut Pierre Simon Laplace/Service d'Aéronomie, Université Pierre et Marie Curie, Paris, France \\ ${ }^{2}$ Centre National de Recherches Météorologiques, Météo-France, Toulouse, France \\ ${ }^{3}$ Institut National des Sciences de l'Univers, Division Technique, Meudon, France \\ ${ }^{4}$ Institut für Physik der Atmosphäre, Deutsches Zentrum für Luft- und Raumfahrt, Oberpfaffenhofen, Germany
}

Received: 26 January 2006 - Revised: 12 June 2006 - Accepted: 23 June 2006 - Published: 9 August 2006

\begin{abstract}
Sea-breeze dynamics in southern France is investigated using an airborne Doppler lidar, a meteorological surface station network and radiosoundings, in the framework of the ESCOMPTE experiment conducted during summer 2001 in order to evaluate the role of thermal circulations on pollutant transport and ventilation. The airborne Doppler lidar WIND contributed to three-dimensional (3-D) mapping of the sea breeze circulation in an unprecedented way. The data allow access to the onshore and offshore sea breeze extents $\left(x_{s b}\right)$, and to the sea breeze depth $\left(z_{s b}\right)$ and intensity $\left(u_{s b}\right)$. They also show that the return flow of the sea breeze circulation is very seldom seen in this area due to (i) the presence of a systematic non zero background wind, and (ii) the 3-D structure of the sea breeze caused by the complex coastline shape and topography. A thorough analysis is conducted on the impact of the two main valleys (Rhône and Durance valleys) affecting the sea breeze circulation in the area.
\end{abstract}

Finally, this dataset also allows an evaluation of the existing scaling laws used to derive the sea breeze intensity, depth and horizontal extent. The main results of this study are that (i) latitude, cumulative heating and surface friction are key parameters of the sea breeze dynamics; (ii) in presence of strong synoptic flow, all scaling laws fail in predicting the sea breeze characteristics (the sea breeze depth, however being the most accurately predicted); and (iii) the ratio $z_{s b} / u_{s b}$ is approximately constant in the sea breeze flow.

Keywords. Meteorology and atmospheric dynamics (Mesoscale meteorology; Turbulence; General or miscellaneous)

Correspondence to: P. Drobinski

(philippe.drobinski@aero.jussieu.fr)

\section{Introduction}

The ESCOMPTE program ${ }^{1}$ (Cros et al., 2004; Mestayer et al., 2005), conducted in June and July 2001 aims at improving the understanding and the forecast of the pollutants' behavior during photo-chemical episodes in Provence, southern France (region shown in Fig. 1). The high occurrence of pollution events in this region during summertime is due to the combination of the presence of the large city of Marseille and its industrialized suburbs (oil plants in the Fos-Berre area) as sources of pollutants, and the intense solar heating that enhances photochemical activity. The pollutants emitted close to the shoreline are transported from the sources in a manner that depends on the dominant atmospheric circulation of the day. In this region, two major flow regimes alternate during summertime: (i) the Mistral which results from the channelling of a northerly flow within the Rhône valley between the French Alps (highest elevation, $4807 \mathrm{~m}$ ) and the Massif Central (highest elevation, $1885 \mathrm{~m}$ ) (see Fig. 1) (Drobinski et al., 2005) and transports pollutants offshore (Corsmeier et al., 2005); (ii) the sea breeze induced by the sea land temperature contrast which advects the pollutants as far as $100 \mathrm{~km}$ inland thus affecting the inhabitants leaving in the countryside. The interaction of these flows together and with the topography at different scales is a source of complexity which affects our understanding of the regional flow dynamics and the related distribution of pollutants over Provence. The documentation of sea breeze circulations in different atmospheric circumstances is key to addressing this issue.

In 2001, the period of the ESCOMPTE campaign was particularly favorable to pollution events associated with sea breeze circulation and several intensive observing periods (IOP) were carried out allowing a robust description of

\footnotetext{
${ }^{1}$ Expérience sur Site pour COntraindre les Modèles de Pollution atmosphérique et de Transport d'Emissions (i.e. field experiment to constrain models of atmospheric pollution and emissions transport)
} 
the sea breeze structure. While the determination of atmospheric flow at different heights is a basic requirement for the documentation and understanding of sea breeze circulation, most of the previous observational studies have relied on the time series of meteorological surface stations to characterize sea breezes (Lyons, 1972; Keen and Lyons, 1978; Simpson, 1994; Burton, 2000; Moorthy et al., 2003), used cumuli formed at the front (Lyons, 1972) as tracer of the sea breeze front location in satellite imagery (Burton, 2000) or parachute-borne sondes (Holland and McBride, 1989) and more recently, surface-based active remote sensors such as Doppler radars (Atlas, 1960; Hadi et al., 2002; Lee and Shun, 2003) or lidars (Banta et al., 1993; Banta, 1995; Darby et al., 2002; Bastin et al., 2005; Lemonsu et al., 2006) to document the vertical structure of the sea breeze. During ESCOMPTE, the use of the airborne Doppler lidar WIND (Wind Infrared Doppler lidar) opens the additional spatial dimension and allows the retrieval of the wind field in a two-dimensional plane along the flight track by measuring the motions of aerosol particles in the clear-air or partially cloudy atmosphere (Werner et al., 2001). The dataset provided by the airborne Doppler lidar allows a unique insight into the three dimensional structure of the sea breeze and a thorough validation of research and numerical weather prediction models. Indeed, a reliable and accurate prediction of the inland penetration of the sea breeze, both its depth and intensity, is essential for pollution event forecasting given that the complex terrain of the ESCOMPTE target area is a source of perturbation of the main sea breeze features that put numerical weather prediction models with coarse resolution in a difficult situation.

This article makes use of the data from the airborne Doppler lidar WIND which, when combined with the measurements by operational meteorological surface stations and radiosoundings, give a robust description of the sea breeze structure using the numerous documented cases, and identify the most salient features in the complex environment of the ESCOMPTE target area. Specifically, this study aims at:

- characterizing the sea breeze in terms of inland penetration, depth and intensity,

- investigating the impact of the prevailing synoptic flow and the effect of the local topography features on the sea breeze 3-D structure, and

- evaluating theoretical predictions of the main sea breeze features (inland penetration, depth and intensity).

Following the introduction in Sect. 1, the ESCOMPTE field experiment is briefly described in Sect. 2: the data set is presented and the environmental conditions specific to the investigated sea breeze cases are detailed. In Sect. 3, the main breeze features derived from the wind and temperature measurements by the airborne Doppler lidar WIND, the radiosoundings and the operational meteorological surface net- work are presented. Section 4 gives an overview of the existing sea breeze scaling laws while Sect. 5 compares the measurements with the theoretical predictions and discusses the results of the comparison. Section 6 concludes the study.

\section{The ESCOMPTE experiment}

\subsection{Brief description of the synoptic environment of the} documented sea breeze cases

The period and the site of the ESCOMPTE campaign were particularly favorable to the pollution event studies. In one month, no less than 11 days were affected by atmospheric pollution (Cros et al., 2004). In this context, four IOPs were carried out with different local meteorological conditions, two of them being documented with the airborne Doppler lidar WIND. IOP 2 started on 21 June and ended on 26 June 2001. It was decided to separate this IOP into two contiguous parts, $2 \mathrm{a}$ and $2 \mathrm{~b}$, since meteorological conditions changed significantly on 23 June 2001 . The IOP separation point was fixed at 17:00 UTC. The IOP2a period corresponds to the end of a Mistral situation with a moderate northwesterly to westerly wind, clear skies, hot temperature $\left(>30^{\circ} \mathrm{C}\right)$. Marseille and Fos-Berre plumes extended towards the east and over the sea (see Fig. 1c). Highest surface ozone concentrations were found around Toulon, in the easternmost part of the ESCOMPTE domain. The IOP2b best characterizes a pollution event. During these three windless days, temperatures were hot $\left(>34^{\circ} \mathrm{C}\right)$ and surface ozone concentrations reached high values (125 ppbv throughout Aix-en-Provence on 24 June 2001; $100 \mathrm{ppbv}$ over the whole domain and up to $150 \mathrm{ppbv}$ in the Durance valley on 25 June 2001; $115 \mathrm{ppbv}$ in the Rhône valley on 26 June 2001 with a light southerly wind). This episode was heavily documented. IOP 3 started on 2 July and ended on 4 July 2001 and was a short but interesting episode characterized by a sea breeze interacting with a large-scale flow veering from the northwest to the southwest in altitude and blowing from the south/southwest near the surface. On the last day, the southwesterly wind became stronger and cloudiness appeared in the domain.

\subsection{Dataset}

During the ESCOMPTE experiment, a wide range of instruments was deployed around Marseille (Cros et al., 2004; Mestayer et al., 2005). In the present study, we use the measurements from the airborne Doppler lidar WIND, the radiosoundings and the synoptic meteorological surface stations of Météo-France. The complementary nature of the data provided by these various instruments is an essential aspect of this study. The locations of the operational meteorological surface stations are shown with dots in Fig. 1. 

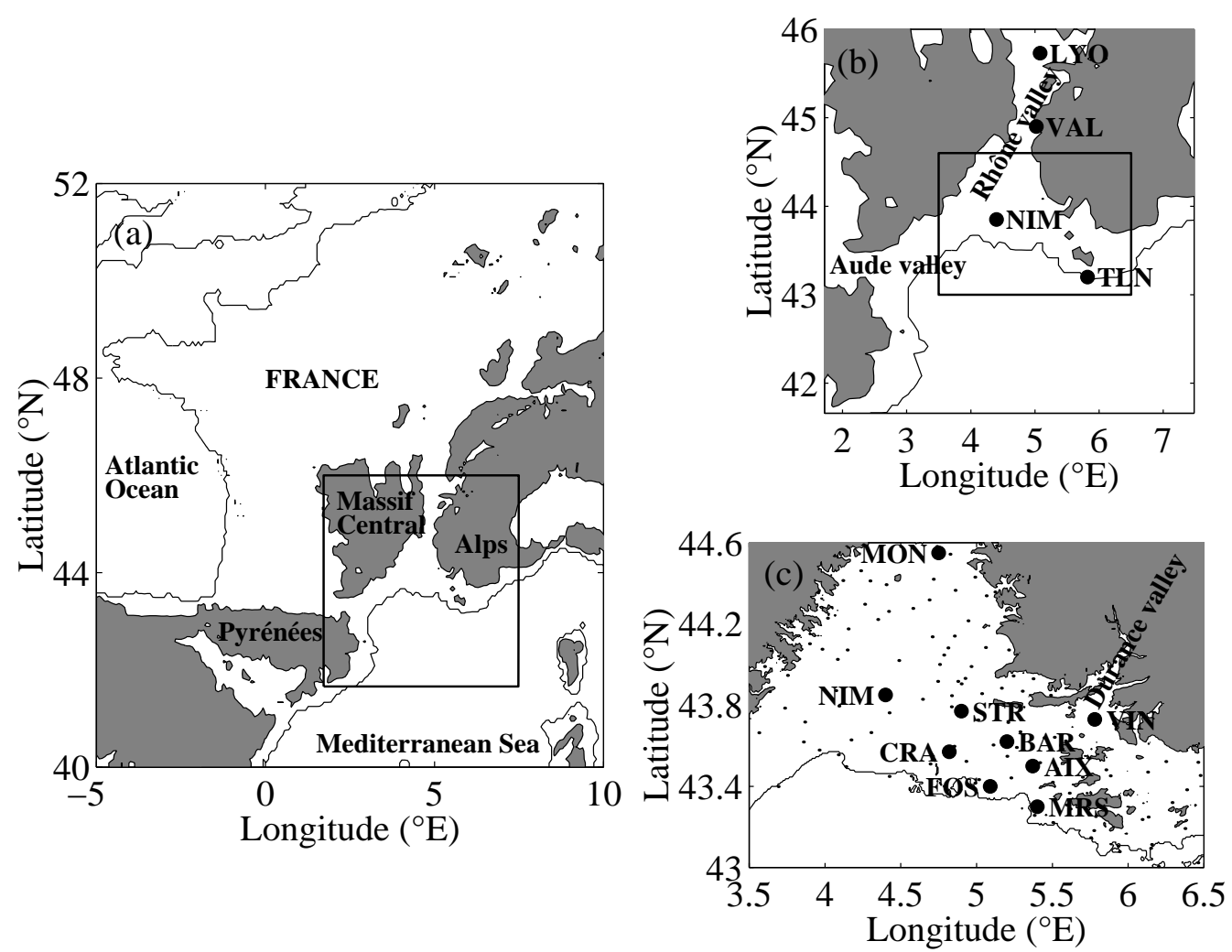

Fig. 1. Panel (a): Map of France with the topography shaded in grey when higher than $500 \mathrm{~m}$ above sea level. The rectangle displays the region shown in panel b. Panel (b): Zoom corresponding to the region shown by a rectangle in panel (a). The acronyms NIM, LYO, TLN and VAL indicate the cities of Nîmes, Lyon, Toulon and Valence, respectively. Panel c: Zoom corresponding to the region shown by a rectangle in panel (b). The dots indicate the locations of the operational meteorological surface stations operated by Météo-France. The acronyms AIX, BAR, CRA, FOS, MON, MRS, STR and VIN indicate the cities of Aix en Provence, Barben, la Crau, Fos-Berre, Montélimar, Marseille, Saint Rémy de Provence and Vinon, respectively.

\subsubsection{Radiosoundings and in-situ surface stations}

Operational radiosondes were released every twelve hours from Lyon and Nîmes (see Fig. 1b). Additional radiosoundings were launched during IOPs from Nîmes and other sdtations (Aix en Provence, Marseille, Saint Rémy de Provence and Vinon see Fig. 1c). At the surface, the operational meteorological surface station network gave access to the hourly surface thermodynamical field (wind speed and direction at $10 \mathrm{~m}$ height; temperature, humidity and pressure at $2 \mathrm{~m}$ height. The pressure measurements are available only at very few stations) (see dots in Fig. 1c). In addition to this network, several stations providing radiative and turbulent flux measurements were deployed for the campaign. They were located at Marseille, Barben, la Crau and Vinon (see Fig. 1c), with the stations located at Marseille being the only urban stations.

\subsubsection{The airborne Doppler lidar WIND}

The airborne Doppler lidar WIND was developed in a French-German cooperation between the Centre National de la Recherche Scientifique (CNRS), the Centre National d'Études Spatiales (CNES), and the Deutsches Zentrum für Luft- und Raumfahrt (DLR). The lidar is operated at $10.6 \mu \mathrm{m}$ in the infrared spectral region and during ESCOMPTE was on board of the DLR Falcon 20 (Werner et al., 2001), flying at an altitude of $6.5 \mathrm{~km}$ with an aircraft ground speed of about $170 \mathrm{~m} \mathrm{~s}^{-1}$. At $10.6 \mu \mathrm{m}$ wavelength, the lidar signals are sensitive to micronic aerosols which are excellent tracers of the dynamics in troposphere, therefore making WIND a relevant tool for the study of planetary boundary layer (PBL) dynamics in complex terrain (Reitebuch et al., 2003; Bastin et al., 2005, 2006; Drobinski et al., 2005). The Doppler lidar WIND provides wind radial velocity measurements along the line-of-sight (LOS) of the transmitted laser beam. The wind profile is obtained by conically scanning the LOS around the vertical axis with a fixed angle of $30^{\circ}$ from nadir. The profile of the 3-D wind vector is calculated from the profiles of the LOS wind speeds using a velocity-azimuthal display (VAD) technique (Caya and Zawadzki, 1992). A full scan revolution of the line-of-sight takes $20 \mathrm{~s}$, leading to a horizontal resolution of about $3.4 \mathrm{~km}$ between vertical profiles of the wind 

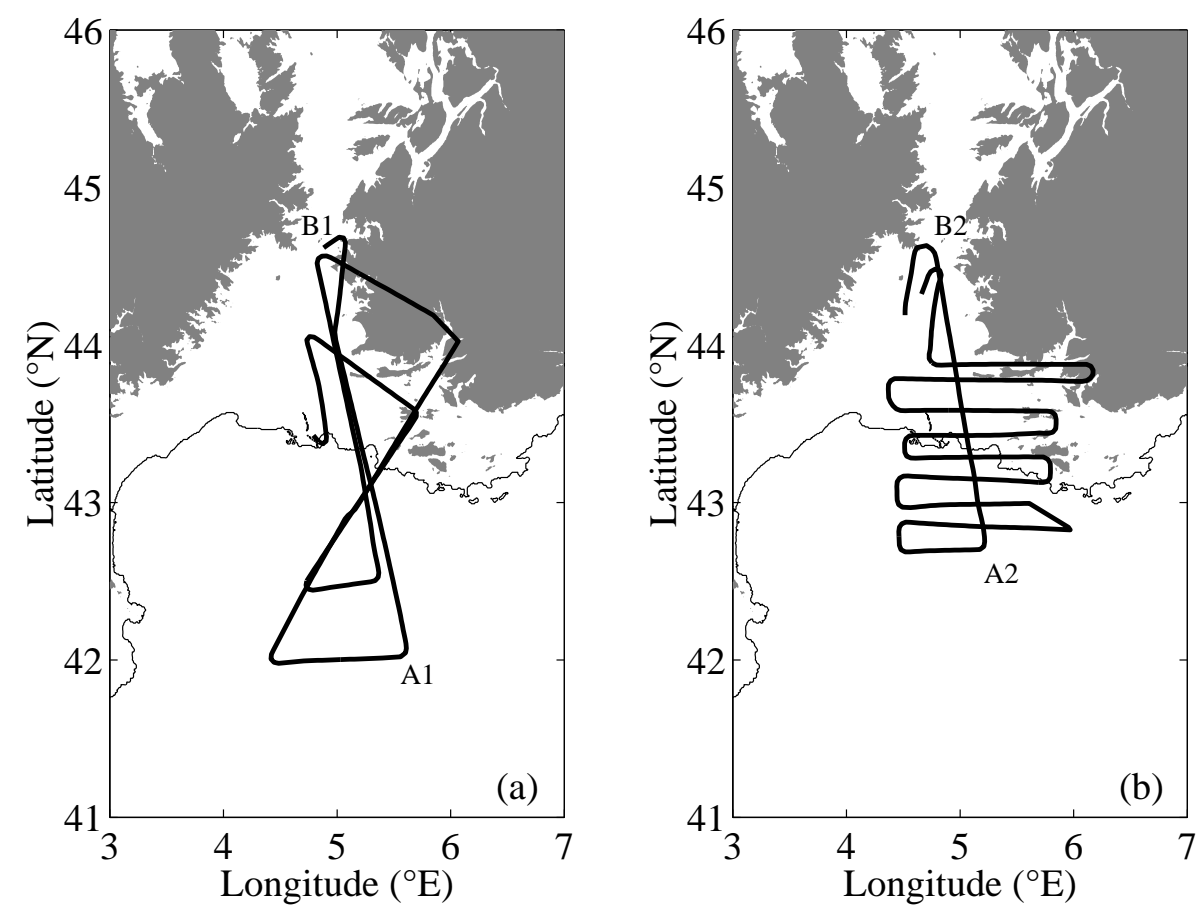

Fig. 2. The two typical flight tracks of the DLR Flacon 20 carrying the Doppler lidar WIND on board. Flight track of panel a is called "transect track" (hereafter denoted track TRAN); flight track of panel b is called "exploration track" (hereafter denoted track EXPL). The topography is shaded in grey when higher than $500 \mathrm{~m}$ above sea level.

Table 1. Scientific flights during ESCOMPTE. TRAN and EXPL correspond to typical flight tracks. Tracks TRAN (for "transect" track) and EXPL (for "exploration" tack) are shown in Fig. 2.

\begin{tabular}{ccccc}
\hline Date & Hours (UTC) & Track & IOP & Comments \\
\hline 22 June 2001 & $16: 28-17: 10$ & TRAN & 2a/D+1 & Breeze/Mistral combination - Medium level quality data \\
24 June 2001 & $10: 20-13: 00$ & EXPL & 2b/D+1 & End of Mistral - No sea breeze - High quality data \\
25 June 2001 & $16: 50-19: 32$ & TRAN & 2b/D+2 & Sea-breeze - High quality data \\
26 June 2001 & $12: 27-15: 38$ & EXPL & 2b/D+3 & Sea-breeze - High quality data \\
3 July 2001 & $13: 45-16: 30$ & TRAN & 3/D+1 & Sea-breeze - High quality data \\
4 July 2001 & $13: 51-16: 30$ & EXPL & 3/D+2 & Sea-breeze - High quality data \\
\hline
\end{tabular}

vector. The vertical resolution of the wind profiles is $250 \mathrm{~m}$ and the accuracy of the horizontal wind velocity is around $1 \mathrm{~m} \mathrm{~s}^{-1}$ (Reitebuch et al., 2001).

Six flights were made by the DLR Flacon with WIND onboard during the IOPs (Table 1).

Typical tracks were flown during ESCOMPTE (Fig. 2 and Table 1). In general, for an IOP starting at day D, WIND flew alternately an "exploration track" (hereafter called EXPL track) and a "transect track" (hereafter called TRAN track) from day+1 (D+1). Track EXPL was dedicated to the documentation of the 3-D wind field in a box in order to compute the advection terms in the chemical species budgets (e.g. in particular ozone budgets). Track TRAN was dedicated to the study of the sea breeze structure along the Rhône and the
Durance valleys in order to investigate the impact of these valleys on the sea breeze dynamics.

\section{Characteristics of the sea breeze circulation from the airborne Doppler lidar, radiosounding and surface station data}

The surface flow pattern at the exit of the Rhône valley is shown in Fig. 3 which displays the surface temperature (at $2-\mathrm{m}$ height) and wind fields (at 10-m height) measured by the operational meteorological network at the approximate time of the airborne Doppler lidar flights. The horizontal representation of the measured temperature is obtained by linearly interpolating the surface measurements of the surface 

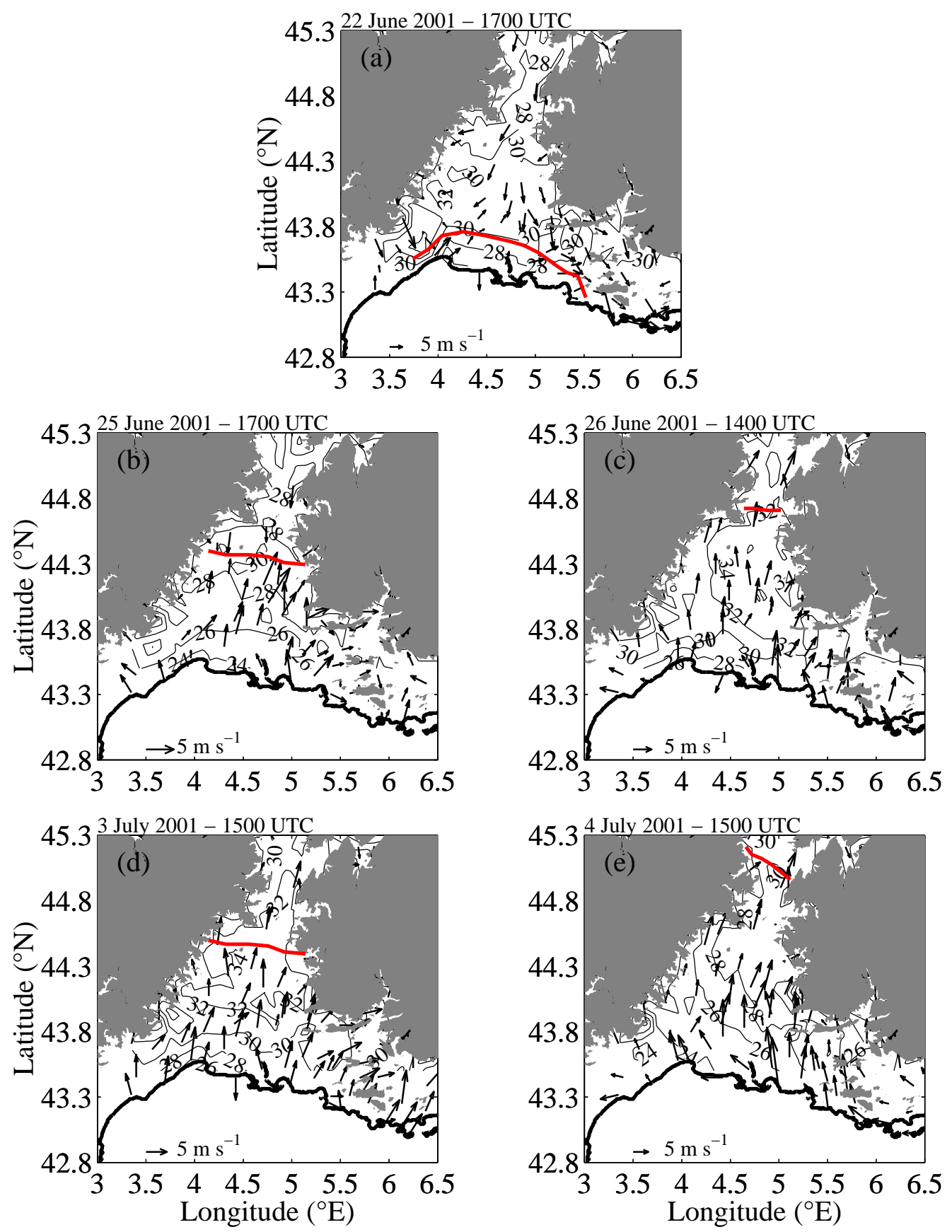

Fig. 3. 10-m wind and 2-m temperature fields from the operational meteorological stations on 22 June at 17:00 UTC (a), 25 June at 17:00 UTC (b), 26 June at 1400 UTC (c), 3 July at 15:00 UTC and 4 July at 15:00 UTC, corresponding approximately to the Falcon flight hours. Arrows indicate the wind speed (see scale) and direction. The isotherms are solid lines with an increment step of $2^{\circ} \mathrm{C}$. The thick red and black lines indicate the location of the sea breeze front and the coastline, respectively. The topography is shaded in grey when higher than $500 \mathrm{~m}$ above sea level.

stations. The sea breeze front location is indicated by a thick red line and corresponds to the location of the temperature maximum or/and (when it exists) the area where the wind reverses from the south (sea breeze flow) to the north. Bastin et al. (2005) and Bastin and Drobinski (2006) show that in this area, the maximum inland penetration of the sea breeze is often found around 16:00 UTC, which coincides with the maximum of the diurnal temperature cycle (note that the local solar time which is a relevant time coordinate for breeze studies corresponds to universal time coordinate (UTC) $+20 \mathrm{~min}$; 


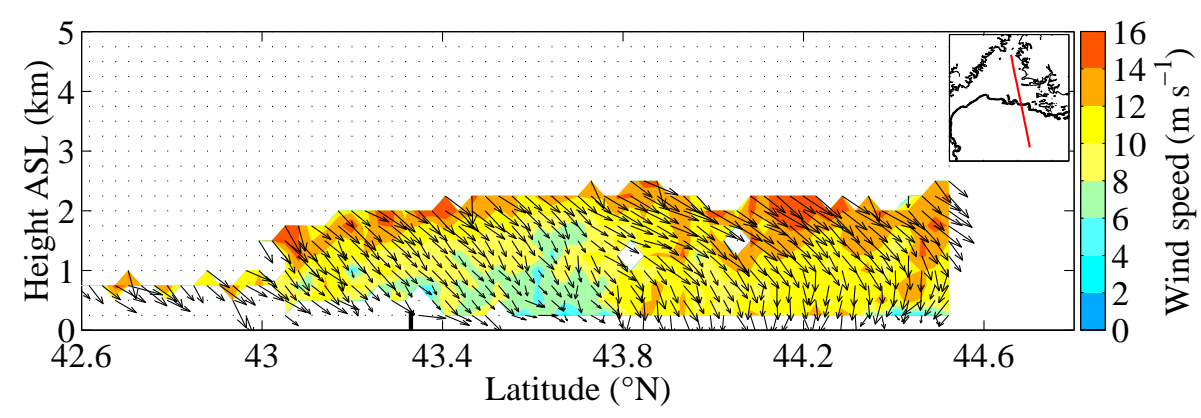

Fig. 4. Small rectangle: Topography of the ESCOMPTE area. The black lines indicate the 500-m isoline and the coastline. The red segments represent the flight track of the DLR Falcon 20 along which the vertical cross section of the horizontal wind field from the WIND data is extracted and shown in the main panel. Main figure: Vertical cross section of the horizontal wind field from the WIND data along the leg shown in the small subpanel on 22 June 2001 at about 17:00 UTC (the time of the entire DLR Falcon 20 flight is given in Table 1). Arrows indicate the horizontal wind speed and direction as a function of height. A northerly wind is a vector aligned with the vertical axis directed downward. The color code indicates the wind speed. The absence of data corresponds to discarded unreliable data flagged using the quality control procedure by Dabas et al. (1999). The dark thick tick indicates the location of the coast. On that leg, the coastline is at about $43.33^{\circ} \mathrm{N}$.

because of this small difference, we use the UTC time unit).

On 22 June 2001 at 17:00 UTC, the sea breeze blows in the Marseille area where it takes a westerly direction because it combines with the Mistral. The observations indicate a large region in the Rhône valley (between 43.7 and $44.4^{\circ} \mathrm{N}$ ) where there is no temperature gradient and where the sea breeze and the Mistral collide (at $43.8^{\circ} \mathrm{N}$ ). Figure 4 displays a vertical cross section of the horizontal wind field from WIND data along the leg shown in the small subpanel at about 17:00 UTC. Arrows indicate the horizontal wind speed and direction (a northerly wind is a vector aligned with the vertical axis directed downward) as a function of height and the superimposed color shading indicates the wind speed. The Mistral is easily discernable with wind speed exceeding $10 \mathrm{~m} \mathrm{~s}^{-1}$ and a pronounced northerly to northwesterly direction. Since the vertical resolution is $250 \mathrm{~m}$, the Doppler lidar observations do not allow documentation of the near surface flow thus it is difficult to distinguish the sea breeze circulation. However, one can see that the near-surface flow has a more pronounced westerly component between 43.5 and $43.8^{\circ} \mathrm{N}$ than north of $43.8^{\circ} \mathrm{N}$ where the flow blows from the north. A large horizontal shear of the horizontal wind is visible at $43.75^{\circ} \mathrm{N}$ up to $1.5 \mathrm{~km}$ height, the wind speed decreasing suddenly from $11-12 \mathrm{~m} \mathrm{~s}^{-1}$ north of this latitude to about $5-6 \mathrm{~m} \mathrm{~s}^{-1}$. Latitude $43.75^{\circ} \mathrm{N}$ is also the location of the sea breeze front detected with the surface stations at 17:00 UTC in Fig. 3. The very small penetration of the sea breeze front is due to the offshore Mistral wind which inhibits the inland progress of the sea breeze (Estoque, 1962) and has detrimental effects on regional air quality (Bastin et al., 2006).

On 25 June at about 17:00 UTC, the surface wind and temperature fields clearly show the sea breeze establishment and the front location (Fig. 3). The sea breeze front has penetrated inland with a propagation speed of about $3-5 \mathrm{~m} \mathrm{~s}^{-1}$ (Bastin and Drobinski, 2006) and stabilizes at the time of the leg between $44.2^{\circ} \mathrm{N}$ and $44.5^{\circ} \mathrm{N}$, corresponding to an inland penetration ranging between 70 and $100 \mathrm{~km}$ in the Rhône valley. Figure 5a shows that along the Rhône valley at about 17:00 UTC, the sea breeze is characterized by a southerly to southwesterly flow never exceeding $5 \mathrm{~m} \mathrm{~s}^{-1}$. The transition between the upper-level synoptic flow is exhibited by a strong wind direction shift and an increase of the wind speed. In situations when the synoptic flow and the sea breeze blow in the same direction, we use the PBL depth as a tracer of the sea breeze depth (Rotunno , 1983; Feliks, 1963, 1993; Bastin et al., 2005). Figure 5a shows that the full sea breeze cell has been documented both over land and over the sea, which is a quite unique data set. The inland penetration is at about $44.3^{\circ} \mathrm{N}$, in good agreement with the surface measurements, while the offshore limit of the breeze cell is at about $42^{\circ} \mathrm{N}$, showing evidence of breeze cell asymmetry (as for the 22 June 2001 case) which is consistent with an adverse northerly low-level wind blowing from the Rhône valley (Estoque, 1962). Figure 5a also shows a large spatial variability of the sea breeze vertical extent; at the offshore and onshore cell limits, the sea breeze extends up to $300 \mathrm{~m}$ while it reaches $1200 \mathrm{~m}$ south of the coastline. The sea breeze flow velocity estimated from the WIND data is about $4-4.5 \mathrm{~m} \mathrm{~s}^{-1}$ along the leg.

Along a leg intended to document the sea breeze within the Durance valley, Fig. 5b shows that the southerly flow deepens and strengthens above the sea between $42^{\circ} \mathrm{N}$ to $42.5^{\circ} \mathrm{N}$ since the south part of this leg is within the easterly edge of a cyclonic circulation associated with a surface pressure low over Spain. In the Durance valley, Fig. 5b shows that, as the sea breeze flow enters the Durance valley at $43.7^{\circ} \mathrm{N}$, it accelerates $\left(+3 \mathrm{~m} \mathrm{~s}^{-1}\right)$ and deepens $(+500 \mathrm{~m})$ due to valley constriction (Drobinski et al., 2001). Across the hill and perpendicular to the Rhône valley, Fig. 5c shows the acceleration and channelling of the sea breeze flow in the Durance 

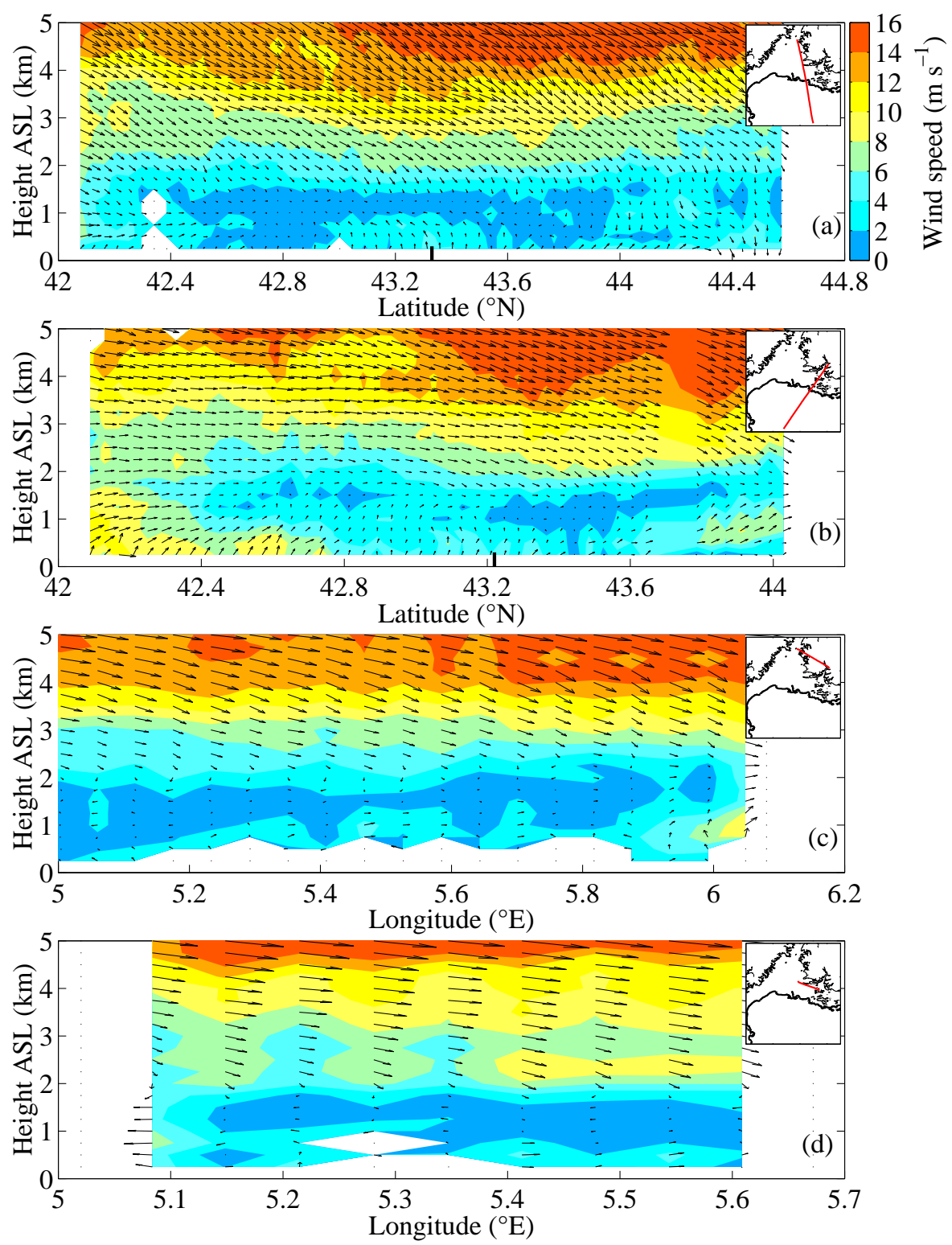

Fig. 5. Same as Fig. 4 but on 25 June 2001 at about 17:00 UTC (the time of the entire DLR Falcon 20 flight is given in Table 1). On panels (a) and (b), the coastline is at about $43.33^{\circ} \mathrm{N}$ and $43.22^{\circ} \mathrm{N}$, respectively.

valley east of $5.8^{\circ} \mathrm{E}$ longitude. Indeed, the zone where the flow accelerates and is directed along the Durance valley axis is confined below the mountain crest and between the valley sidewalls. Along the southern foothills of the Alpine ridge, Fig. 5d clearly shows evidence of flow splitting of the southerly sea breeze impinging on the mountain. Below $1 \mathrm{~km}$ above ground level (AGL), the flow takes a westerly direction east of $5.3^{\circ} \mathrm{E}$ longitude and takes an easterly direction west of $5.3^{\circ} \mathrm{E}$ longitude. Above $1 \mathrm{~km}$ AGL, the northwesterly large-scale flow blows. Flow splitting around the massif occurs when the upstream Froude number $F r=U / \sqrt{g^{\prime} h}$ is sufficiently small $(F r<1)(U$ is the upstream wind velocity, $g^{\prime}=g \Delta \theta / \theta$ is the reduced gravity acceleration, $\theta$ is the average potential temperature in the PBL and $\Delta \theta$ is the change in potential temperature from near the surface to above the ridge height $h$ upwind of the ridge $h$ ). The radiosounding launched from Nîmes at 12:00 UTC on 25 June 2001 gives $U=3 \mathrm{~m} \mathrm{~s}^{-1}$, $\theta=302 \mathrm{~K}$ and $\Delta \theta=3.5 \mathrm{~K}$, leading to $F r=0.2$ for a downstream orography height $h=2000 \mathrm{~m}$. The height $z_{s}$ of the splitting point for low Froude number flows can be approximated by $z_{s}=h(1-2 F r)$ (Baines, 1979), giving $z_{s}=1200 \mathrm{~m}$ which is to be compared to the observed $1000 \mathrm{~m}$ (Fig. $5 \mathrm{~d}$ ). 

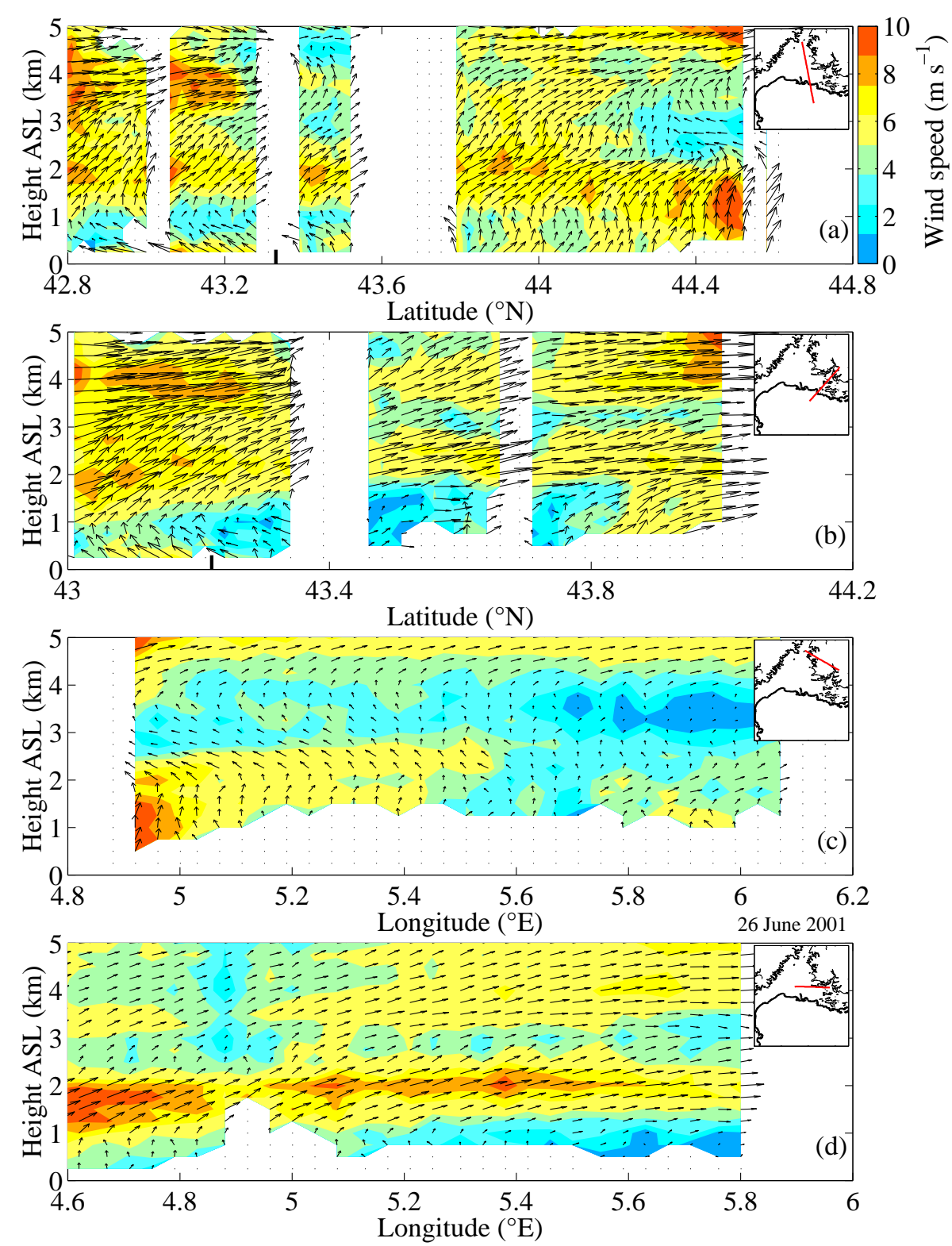

Fig. 6. Same as Fig. 4 but on 26 June 2001 at about 14:00 UTC (the time of the entire DLR Falcon 20 flight is given in Table 1). On panels (a) and (b), the coastline is at about $43.33^{\circ} \mathrm{N}$ and $43.22^{\circ} \mathrm{N}$, respectively.

On 26 June 2001, the situation differs from 25 June 2001 since a prevailing moderate synoptic southwesterly flow combines with the sea breeze (see wind direction above 2km height in Fig. 6) and penetrates into the Rhône and Durance valleys. The onshore wind weakens the temperature gradient along the Rhône valley and the sea breeze penetrates further inland (Arritt, 1993). Indeed, Fig. 3 shows that at 14:00 UTC, the front has already penetrated further inland than on 25 June 2001 at 17:00 UTC and the sea breeze front is located between Montélimar and Valence at about $44.8^{\circ} \mathrm{N}$ (see Fig. 1c). Figure 6a shows that over the Mediterranean, the sea breeze takes a southeasterly direction and turns to the south in the Rhône valley north of $43.8^{\circ} \mathrm{N}$ due to channelling by the Rhône valley. Below $1.5 \mathrm{~km}$ height, channelling due to valley constriction provokes the increase of the wind speed by about $2 \mathrm{~m} \mathrm{~s}^{-1}$.

Figure $6 \mathrm{~b}$ shows that the flow is oriented from the southeast south of $43.3^{\circ} \mathrm{N}$ which corresponds to the main direction of the sea breeze in this part of the domain. Between $43.3^{\circ} \mathrm{N}$ and $43.8^{\circ} \mathrm{N}$, the wind speed decreases below $2 \mathrm{~m} \mathrm{~s}^{-1}$ and the wind direction is highly variable. This low wind speed area is caused by stagnation as the flow impinges on the hills. The sea breeze flow re-accelerates north of $43.8^{\circ} \mathrm{N}$ as it enters the Durance valley $\left(+4 \mathrm{~m} \mathrm{~s}^{-1}\right)$ (Bastin et al., 2005). The effect of 

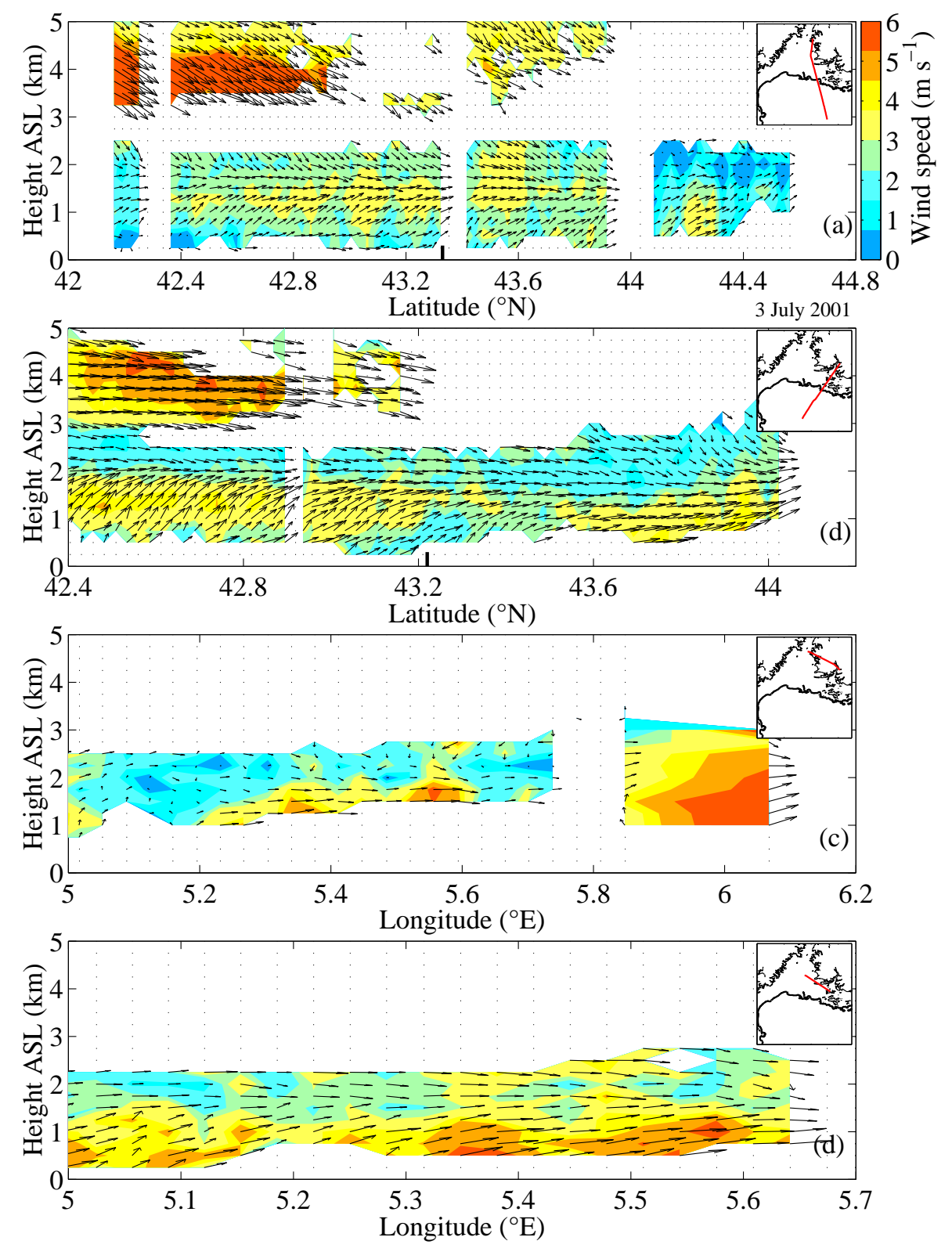

Fig. 7. Same as Fig. 4 but on 3 July 2001 at about 15:00 UTC (the time of the entire DLR Falcon 20 flight is given in Table 1). On panels (a) and (b), the coastline is at about $43.33^{\circ} \mathrm{N}$ and $43.22^{\circ} \mathrm{N}$, respectively.

the Rhône valley on the sea breeze flow is also visible on the cross section shown in Fig. 6c which intersects the Rhône and Durance valleys. Indeed, contrary to the 25 June 2001 case (see Fig. 5c), flow acceleration occurs within the Rhône valley west of $5.2^{\circ} \mathrm{E}$ below the crest $\left(+2 \mathrm{~m} \mathrm{~s}^{-1}\right.$ with respect to the wind intensity south of $44.4^{\circ} \mathrm{N}$, see Fig. 6 a). In the Durance valley (between 5.8 and $6.05^{\circ} \mathrm{E}$ ), a core of higher wind speed below the crest line is visible revealing channelling in the valley. In the cross-section shown in Fig. 6d, flow splitting is once again visible at the mountain foothills at a similar height as on 25 June $2001, z_{s} \simeq 1 \mathrm{~km}$ (on 26 June 2001, the ra- diosounding and WIND data give a Froude number $F r \simeq 0.3$, leading to a predicted $z_{s} \simeq 0.8 \mathrm{~km}$ ).

On 3 July 2001, a prevailing wind blows from the west/northwest but does not penetrate within the Rhône valley where a large-scale moderate southerly/southwesterly wind blows. Figure 3 shows that at 15:00 UTC, the temperature maximum is located at about $44.5^{\circ} \mathrm{N}$ which marks the horizontal limit of the sea breeze flow. At 15:00 UTC, the sea breeze front has thus penetrated as far as $110 \mathrm{~km}$ inland. Figure 7a shows the separation between the southwesterly sea breeze flow and the northwesterly synoptic flow at 

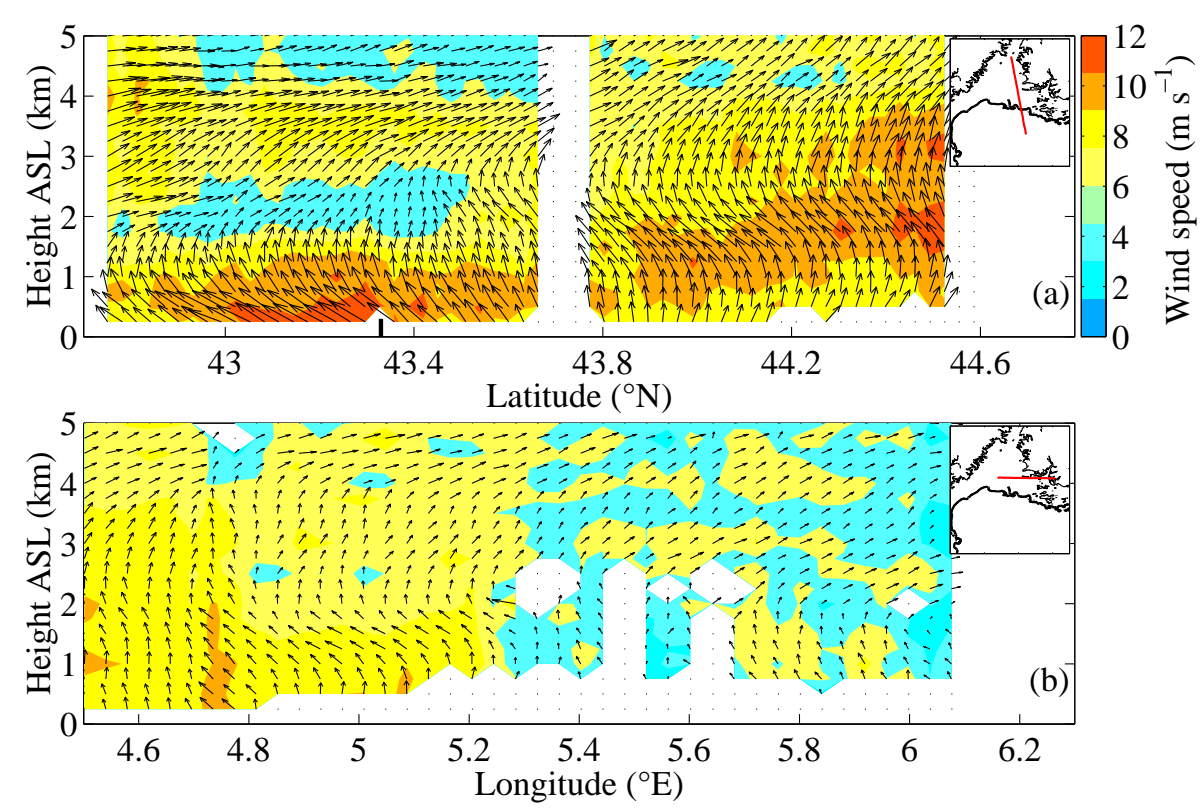

Fig. 8. Same as Fig. 4 but on 4 July 2001 at about 15:00 UTC (the time of the entire DLR Falcon 20 flight is given in Table 1). On panel (a), the coastline is at about $43.33^{\circ} \mathrm{N}$.

about $1.5 \mathrm{~km}$ height. The sea breeze intensity is constant and equal to about $4-5 \mathrm{~m} \mathrm{~s}^{-1}$ along the section and takes a southwesterly direction south of $44.0^{\circ} \mathrm{N}$. North of $44.0^{\circ} \mathrm{N}$, the Rhône valley contributes to accelerating the flow.

In the Durance valley, the acceleration of the flow experiencing lateral constriction is detectable north of $43.6^{\circ} \mathrm{N}$ because the wind aligns with the valley axis and increases from 5 to $7 \mathrm{~m} \mathrm{~s}^{-1}$ (Fig. 7a). The depth of the sea breeze varies along the cross-section. Unlike the 26 June 2001 sea breeze case, the sea breeze depth becomes shallower as the sea breeze enters the Durance valley revealing the supercritical regime of the sea breeze flow (Drobinski et al., 2001). Figure 7 (panels $\mathrm{c}$ and d) show that the sea breeze circulation has a more pronounced westerly component in the Rhône valley than on 25 June 2001 (see Fig. 5d) so the location of the split point differs from the 25 June 2001 case. In Fig. 7c, the southwesterly sea breeze flow is deflected and redirected in the direction of the Durance valley and flows along the mountain flank. Indeed, east of $5.2^{\circ} \mathrm{E}$, the flow turns from the southwest to the west-southwest.

Similar to the 26 June 2001 sea breeze case, the 4 July 2001 sea breeze case features a superimposed southwesterly synoptic flow. Figure 3 shows that at 15:00 UTC on 4 July 2001, the sea breeze front has penetrated as far as $150 \mathrm{~km}$ inland. Indeed, the temperature maximum is located at about $45^{\circ} \mathrm{N}$ which marks the horizontal limit of the sea breeze flow. One interesting feature on 4 July 2001 is that as the synoptic southwesterly wind strengthens it tends to distort the near-surface temperature pattern especially in the eastern side of the Rhône valley. The near-surface temperature pattern is no longer parallel to the shore but the temperature gradient aligns along a southwest-northeast direction, nearly parallel to the coastline. This phenomenon is consistent with Arritt (1993) who shows that if the prevailing synoptic onshore flow exceeds about $3 \mathrm{~m} \mathrm{~s}^{-1}$, it inhibits the temperature rise and thus the sea breeze circulation development. On 4 July 2001, the southwesterly flow is thus strong enough to prevent the sea breeze development on the eastern side of the Rhône valley yet it seems to exist on the western side of the Rhône valley, as the near-surface temperature pattern displays a cross-shore gradient. Figure 8a clearly shows a strong low-level flow. The wind speed even exceeds $9 \mathrm{~m} \mathrm{~s}^{-1}$ south of $43.5^{\circ} \mathrm{N}$ which corresponds to the easternmost part of the leg. The wind speed decreases down to about 6$8 \mathrm{~m} \mathrm{~s}^{-1}$ north of $43.8^{\circ} \mathrm{N}$ which is the part of the leg located in the most central part of the Rhône valley which seems to be less affected by the southerly synoptic flow and where the sea breeze blows (see Fig. 3). The vertical cross-section shown in Fig. 8 b enables documentation of the Rhône valley at about $43.8^{\circ} \mathrm{N}$ and one can see that the wind speed within the Rhône valley ranges between 6 and $9 \mathrm{~m} \mathrm{~s}^{-1}$. The wind veers from the southeast to the south/southwest above about $1.5 \mathrm{~km}$ height which indicates the top of the sea breeze flow (in agreement with the stratification measurements collected from the radiosounding launched from Nîmes, not shown). Along this leg, a core of very low wind speed (about $2 \mathrm{~m} \mathrm{~s}^{-1}$ ) is visible between $5.3^{\circ} \mathrm{E}$ and $5.6^{\circ} \mathrm{E}$. This area corresponds to the location where the $1.5 \mathrm{~km}$ depth flow splits between the Rhône and Durance valleys (on 4 July 2001, the radiosounding and WIND data give a Froude number $F r \simeq 0.16$, leading to a predicted split point height $z_{s} \simeq 1.4 \mathrm{~km}$ ). East of $6^{\circ} \mathrm{E}$, the blocking by the mountain foothills also leads to very weak 
wind speed. Between $5.6^{\circ} \mathrm{E}$ and $6^{\circ} \mathrm{E}$, in the Durance valley, the wind speed exceeds $6 \mathrm{~m} \mathrm{~s}^{-1}$ which marks the impact of the Durance valley. The analysis of the two legs as well as the surface temperature and wind pattern also reveals that the sea breeze blowing within the Rhône valley accelerates when reaching the northernmost part of the Rhône valley and that the sea breeze penetrates very far inland (about $150 \mathrm{~km}$ ).

\section{Sea-breeze scaling}

The data from the airborne Doppler lidar, radiosoundings and surface stations allow the ability to check the applicability of simple scaling to describe the sea breeze circulation. Linear theory was broadly used to study the atmospheric response to a simple surface differential heating in the absence (Rotunno , 1983) and in the presence of prevailing wind (Walsh, 1974). The major characteristics of the sea breeze are its intensity $\left(u_{s b}\right)$, depth $\left(z_{s b}\right)$ and aspect ratio which corresponds to the ratio of the sea breeze horizontal extent $\left(x_{s b}\right)$ to its depth. The analytical expressions found for these characteristics are summarized below from a review of the studies addressing scaling of the sea breeze intensity, vertical and horizontal structures. The sea breeze intensity $u_{s b}$ and depth $z_{s b}$ estimations are derived from Steyn scaling analysis (Steyn, 1998, 2003):

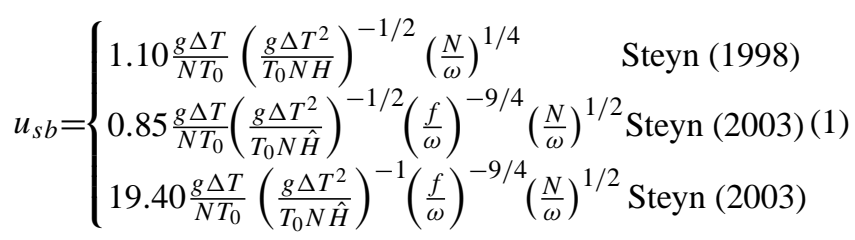

$z_{s b}=\left\{\begin{array}{lr}0.065 \frac{H}{\omega \Delta T}\left(\frac{g \Delta T^{2}}{T_{0} N H}\right)^{1 / 2} & \text { Steyn (1998) } \\ 0.75 \frac{\hat{H}}{\omega \Delta T}\left(\frac{g \Delta T^{2}}{T_{0} N \hat{H}}\right)^{1 / 3}\left(\frac{f}{\omega}\right)^{-5 / 2} & \text { Steyn (2003) } \\ 1.29 \frac{\hat{H}}{\omega \Delta T}\left(\frac{g \Delta T^{2}}{T_{0} N \hat{H}}\right)^{1 / 4}\left(\frac{f}{\omega}\right)^{-5 / 2} & \text { Steyn (2003) }\end{array}\right.$

where $H$ is the instantaneous surface sensible heat flux, $\hat{H}$ is the surface sensible heat flux integrated over all times it has positive values, from morning up to the time of the sea breeze profile measurements by the airborne Doppler lidar WIND. The quantity $g$ is the gravitational acceleration, $\Delta T$ is the mesoscale land-sea temperature difference, $N$ is the Brunt-Väisälä frequency, $f$ is the Coriolis parameter, $\omega=7.27 \times 10^{-5} \mathrm{~s}^{-1}$ is the diurnal frequency, and $T_{0}$ is the base state potential temperature and is taken as the vertically averaged thermal internal boundary layer potential temperature. One has to note that Steyn (1998) uses the instantaneous surface-layer turbulent heat flux values in constructing the scaling laws whereas Steyn (2003) uses integrated heat flux. This approach is taken since the sea breeze is likely to respond to cumulative heat input into the lower PBL. Steyn (1998) derived their empirical analytical expressions from a data set collected at one location at $49^{\circ} \mathrm{N}$ whereas Steyn (2003) used data sets from several locations which contributed to correcting the Steyn (1998) analysis for latitude dependence [term $f / \omega$ in Eqs. (1) and (2)]. Finally, Steyn (2003) derived two expressions for $u_{s b}$ and $z_{s b}$, the first ones being derived for a long time period whereas the second ones being derived for one single day. Equations (1) and (2) can be combined to relate the sea breeze intensity $u_{s b}$ to its depth $z_{s b}$ :

$\frac{u_{s b}}{z_{s b}}= \begin{cases}16.92 \omega\left(\frac{N}{\omega}\right)^{1 / 4} & \text { Steyn (1998) } \\ 1.13\left(\frac{g \Delta T^{2}}{T_{0} N \hat{H}}\right)^{1 / 6}\left(\frac{f}{\omega}\right)^{1 / 4}\left(\frac{N}{\omega}\right)^{1 / 2} & \text { Steyn (2003) (3) } \\ 15.04\left(\frac{g \Delta T^{2}}{T_{0} N \hat{H}}\right)^{-1 / 4}\left(\frac{f}{\omega}\right)^{1 / 4}\left(\frac{N}{\omega}\right)^{1 / 2} \text { Steyn (2003) }\end{cases}$

These relations can be compared to that of Green and Dalu (1980) obtained from the analytical derivation of the potential energy produced by surface heating available to mesoscale atmospheric motion:

$\frac{u_{s b}}{z_{s b}}=0.3317 \mathrm{~N}$

Concerning the aspect ratio $x_{s b} / z_{s b}$, several expressions were derived by different authors and are summarized below:

$\frac{x_{s b}}{z_{s b}}= \begin{cases}N /\left(f^{2}-\omega^{2}\right)^{1 / 2} & \text { Rotunno (1983) } \\ N /\left(f^{2}+\lambda^{2}\right)^{1 / 2} & \text { Dalu and Pielke (1989) } \\ N / \omega & \text { Niino (1987); Steyn (1998) }\end{cases}$

where $\lambda^{-1}$ is a damping time due to friction and $\lambda$ is set to $1.2 \omega$ in Dalu and Pielke (1989).

\section{Discussion}

These expressions can be seen as excellent diagnostics for mesoscale pollutant transport and dilution predictions, but they need thorough evaluation against observations. Table 2 summarizes the structural characteristics of the sea breeze cells during the days documented by the airborne Doppler lidar, the radisoundings and the surface station network. The definition of the land-sea temperature difference $\Delta T$ is that of Steyn (1998): the sea temperature is obtained from NOAA AVHRR measurements. In the coastal zone, the temperature continuously increases with distance from its over water value through values determined by cool air advection over the near-shore land, to values characteristic of overland air out of influence of the sea breeze. The land temperature is taken far from marine influence in fetch distance of at least the horizontal sea breeze length scale and is easily estimated from Fig. 3 at the time of the airborne Doppler lidar flight. The Brunt-Väisälä frequency is estimated from the radiosoundings launched from Nîmes. The surface sensible heat flux was measured at different locations in the Marseille city center and its less densely urbanized area (northern suburbs) as well as in the rural area (Vinon, Barben and la Crau). 
Table 2. Sea breeze inland penetration range and depth as derived from the airborne Doppler lidar measurements and the surface wind and temperature data from the operational meteorological network. The aspect ratio is defined as the ratio of the sea breeze inland penetration and the sea breeze depth.

\begin{tabular}{ccccccccc}
\hline Date & $\begin{array}{c}u_{s b} \\
\left(\mathrm{~m} \mathrm{~s}^{-1}\right)\end{array}$ & $\begin{array}{c}x_{s b} \\
(\mathrm{~km})\end{array}$ & $\begin{array}{c}z_{s b} \\
(\mathrm{~km})\end{array}$ & Aspect ratio & $\begin{array}{c}H / \hat{H} \\
\left(\mathrm{~W} \mathrm{~m}^{-2}\right)\end{array}$ & $\begin{array}{c}N \\
\left(\times 10^{-2} \mathrm{~s}^{-1}\right)\end{array}$ & $\begin{array}{c}\Delta T \\
(\mathrm{~K})\end{array}$ & $\begin{array}{c}T_{0} \\
(\mathrm{~K})\end{array}$ \\
\hline 22 June 2001-17:00 UTC & 5.5 & 50 & 0.7 & 71 & $212 / 270$ & 1.7 & 9.3 & 303 \\
25 June 2001-17:00 UTC & 3.5 & 100 & 1.2 & 83 & $156 / 254$ & 1.5 & 7.1 & 302 \\
26 June 2001-1400 UTC & 3.0 & 120 & 1.2 & 100 & $325 / 243$ & 1.3 & 8.6 & 300 \\
3 July 2001-15:00 UTC & 4.5 & 110 & 1.5 & 73 & $327 / 282$ & 1.2 & 7.5 & 300 \\
4 July 2001-15:00 UTC & 6.5 & 150 & 1.5 & 100 & $312 / 280$ & 1.1 & 5.5 & 298 \\
\hline
\end{tabular}

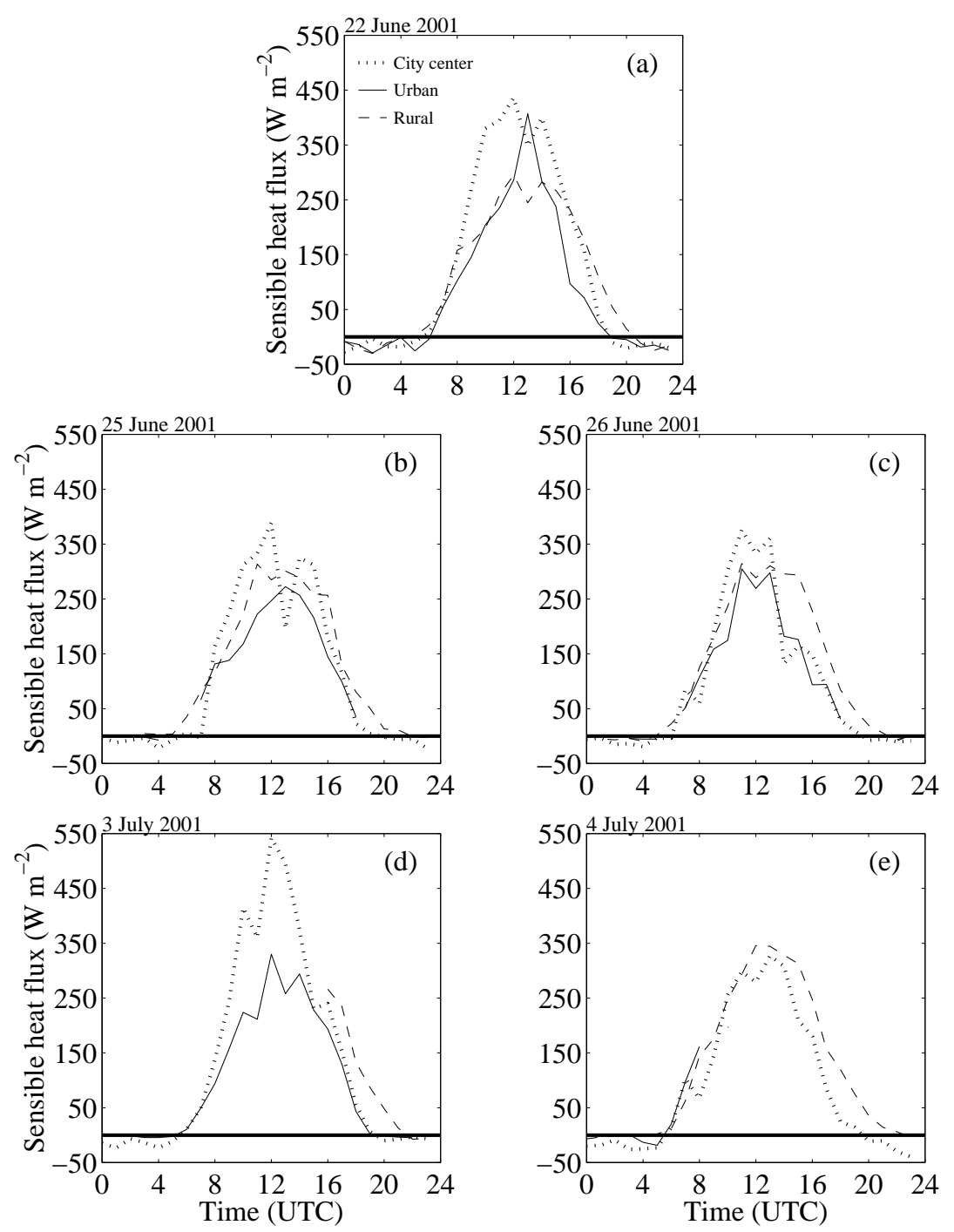

Fig. 9. Surface sensible heat flux measured in the Marseille city center (dotted line), in the less urbanized area of the city (solid line) and in the rural area (dashed line) on 22 June 2001 (a), 25 June 2001 (b), 26 June 2001 (c), 3 July 2001 and 4 July 2001. The thick line corresponds to zero heat flux. 
Table 3. Measured and predicted values [from Steyn scaling analysis] of the speed and depth of the documented sea breeze events near the shoreline.

\begin{tabular}{ccccccc}
\hline Date & \multicolumn{3}{c}{$u_{s b}\left(\mathrm{~m} \mathrm{~s}^{-1}\right)$} & \multicolumn{3}{c}{$z_{s b}(\mathrm{~km})$} \\
& WIND & Steyn (1998) & Steyn (2003) & WIND & Steyn (1998) & Steyn (2003) \\
\hline 22 June 2001 & 5.5 & 2.5 & $4.0 / 3.3$ & 0.7 & 0.5 & $0.9 / 0.9$ \\
25 June 2001 & 3.5 & 2.2 & $3.9 / 3.8$ & 1.2 & 0.5 & $1.1 / 1.1$ \\
26 June 2001 & 4.0 & 3.3 & $3.8 / 2.8$ & 1.2 & 0.7 & $1.0 / 1.0$ \\
03 July 2001 & 3.5 & 3.4 & $4.1 / 3.7$ & 1.5 & 0.8 & $1.2 / 1.2$ \\
04 July 2001 & 6.5 & 3.4 & $4.1 / 4.7$ & 1.5 & 0.8 & $1.4 / 1.5$ \\
\hline
\end{tabular}

Figure 9 shows the diurnal cycle of the surface sensible heat flux at these various locations for the investigated sea breeze days. It shows a large scatter during daytime between the measurements (up to $20 \%$ of the averaged sensible heat flux value) but no trend between rural or urban stations. In the following, we will thus take the average value of the sensible heat flux every hour. When Steyn (1998) analysis is considered, only the averaged sensible heat flux at the time of the WIND flight is used otherwise the time integration of the averaged sensible heat flux is used.

As for the sea breeze aspect ratio, to the authors' knowledge, only Finkele et al. (1995) published measured aspect ratio, which was obtained from aircraft observations across the Coorong coast in South Australia near Woods Well at $36^{\circ} \mathrm{S}$. One has to note that Bastin et al. (2005) published the aspect ratio for the 25 June 2001 sea breeze case, which is reported in this study. This study thus complements those published works and enables a more thorough validation of the expressions summarized in Eq. (5).

The values of $u_{s b}$ and $z_{s b}$ estimated from Steyn scaling analyses are compared to those measured by the WIND measurements, radiosoundings and surface stations (see Table 3 ).

A first result is that Steyn (1998) analysis fails in reproducing our dataset. The derivation of these scaling laws using instantaneous surface sensible heat fluxes at one single latitude of $49^{\circ} \mathrm{N}$ shows that latitude and cumulative heating are key parameters in scaling sea breeze circulation. On the contrary, Steyn (2003) seems to give much better results on 25 and 26 June 2001, and 3 and 4 July 2001. For comparison, Green and Dalu (1980) scaling law [Eq. (4)] using observed $z_{s b}$ leads to $u_{s b}$ values of $3.9,6.0,5.2,6.0$, and $5.5 \mathrm{~m} \mathrm{~s}^{-1}$ for 22, 25, 26 June 2001, 3 and 4 July 2001, respectively. These values overestimate substantially the observed $u_{s b}$ values most probably because the sea breeze is very inefficient at using the energy supplied to it on the right scale (Dalu and Green, 1980).

On 22 June 2001, the sea breeze is strongly affected by the offshore Mistral wind. The Mistral which blows over the sea breeze flow south of $43.8^{\circ} \mathrm{N}$ (Fig. 4) inhibits the vertical extent of the sea breeze by stabilizing the atmospheric stratification just above the sea breeze, as illustrated by the largest value of the Brunt-Väisälä frequency $N=1.7 \times 10^{-2-1}$ (see
Table 3). The Mistral also tends to increase the sea breeze intensity: the Mistral, blowing offshore, increases the surface temperature gradient in the region close to the shore (Estoque, 1962). Indeed, Table 3 shows that the maximum value $\Delta T=9.3 \mathrm{~K}$ is found on 22 June 2001 and that the wind speed is about $6-7 \mathrm{~m} \mathrm{~s}^{-1}$ near the coastline, which is a large value for pure sea breeze circulation. The predicted values of $z_{s b}(0.5 \mathrm{~km}$ in Steyn (1998) and 0.9 in Steyn (2003)) are in the range of uncertainty of the airborne Doppler lidar measurements, whereas the predicted values of $u_{s b}\left(2.5 \mathrm{~m} \mathrm{~s}^{-1}\right.$ in Steyn (1998) and 4.0 and $3.3 \mathrm{~m} \mathrm{~s}^{-1}$ in Steyn (2003)) do not match the observations. The fairly good agreement between the predicted and measured $z_{s b}$ can easily be understood. As shown by Rotunno (1983), the vertical length scale of the sea breeze is only prescribed by external forcing such as surface sensible heat flux and stratification. In the case of pure sea breeze, the horizontal length scale as well as the wind speed will be set internally by the equations of momentum and heat conservation. However, on 22 June 2001, the Mistral imposes a very short external horizontal length scale for the sea breeze which prevails on the internal horizontal length scale. Rotunno (1983) then showed that in this extreme case, the wind speed depends on the external horizontal length scale: the shorter the external horizontal length scale, the larger the wind speed close to the shore. The impact of this external horizontal length scale is not accounted for in Steyn scalings, so the wind speed is underpredicted by Steyn scalings. This situation also affects the estimation of the aspect ratio. Table 4 compares the sea breeze aspect ratios from the different analytical expressions (see Eq. (5)) and the measurements. These aspect ratios are also set internally by the equations of motion, so the internal horizontal length scale is related to the external vertical length scale by the aspect ratio. On 22 June 2001, the values of $N$ obtained from the 12:00 UTC radiosounding launched from Nîmes (NIM in Fig. 1) is $1.7 \times 10^{-2} \mathrm{~s}^{-1}$, so that in the Mistral case, all the expressions for the aspect ratio overpredict considerably the measured aspect ratio $x_{s b} / z_{s b}$. This is due to the fact that the internal horizontal length scale, given by Eq. (5), is much larger than the external length scale imposed by the Mistral offshore flow $\left(x_{s b} \simeq 50 \mathrm{~km}\right)$. 
Table 4. Measured and predicted values of the aspect ratio for the documented sea breeze events. $N$ is the Brunt-Väisälä frequency, $f=1.01 \times 10^{-4} \mathrm{~s}^{-1}$ is the Coriolis parameter at $44^{\circ} \mathrm{N}$ and $\omega=7.27 \times 10^{-5} \mathrm{~s}^{-1}$ is the diurnal frequency. The values of $N$ are obtained from the 12:00 UTC radiosounding launched from Nîmes (NIM in Fig. 1) and are $1.7 \times 10^{-2} \mathrm{~s}^{-1}$ on 22 June $2001,1.5 \times 10^{-2} \mathrm{~s}^{-1}$ on $25 \mathrm{June}$ $2001,1.3 \times 10^{-2} \mathrm{~s}^{-1}$ on 26 June $2001,1.2 \times 10^{-2} \mathrm{~s}^{-1}$ on 3 July $2001,1.1 \times 10^{-2} \mathrm{~s}^{-1}$ on 4 July $2001 . \lambda^{-1}$ is a damping time due to friction and $\lambda$ is set to $1.2 \omega$ in Dalu and Pielke (1989).

\begin{tabular}{ccccc}
\hline Date & Observations & $\begin{array}{c}\text { Aspect ratio } x_{s b} / z_{s b} \\
\text { Rotunno }(1983) \\
N /\left(f^{2}-\omega^{2}\right)^{1 / 2}\end{array}$ & $\begin{array}{c}\text { Dalu and Pielke }(1989) \\
N /\left(f^{2}+\lambda^{2}\right)^{1 / 2}\end{array}$ & $\begin{array}{c}\text { Niino (1987); Steyn }(1998,2003) \\
N / \omega\end{array}$ \\
\hline 22 June 2001 & 71 & 242 & 127 & 233 \\
25 June 2001 & 83 & 213 & 112 & 206 \\
26 June 2001 & 100 & 185 & 97 & 178 \\
3 July 2001 & 73 & 171 & 90 & 165 \\
4 July 2001 & 100 & 157 & 82 & 151 \\
\hline
\end{tabular}

On 25 and 26 June 2001 and 3 July 2001, the predictions of $u_{s b}$ and $z_{s b}$ match the measurements much better. On 25 June 2001, one interesting feature is that the sea breeze depth varies in the direction perpendicular to the coast. It reaches $1.2 \mathrm{~km}$ south of the coastline whereas it culminates at $0.3 \mathrm{~km}$ at the offshore and onshore sea breeze limits. Near the coast, where surface sensible heat fluxes are measured, Steyn (2003) scaling leads to $u_{s b}=3.8-3.9 \mathrm{~m} \mathrm{~s}^{-1}$ and $z_{s b}=1.1 \mathrm{~km}$ compared with the measured values (about $3.5 \mathrm{~m} \mathrm{~s}^{-1}$ and $1.2 \mathrm{~km}$, respectively). Between $43.6^{\circ} \mathrm{N}$ and $44^{\circ} \mathrm{N}$, Fig. $5 \mathrm{~b}$ shows that both the depth and the strength of the sea breeze decrease. At $43.72^{\circ} \mathrm{N}$, the depth is about $500 \mathrm{~m}$, and the maximum velocity is about $2 \mathrm{~m} \mathrm{~s}^{-1}$. One can note that the ratio $z_{s b} / u_{s b} \simeq 300$ remains approximately constant south of $44^{\circ} \mathrm{N}$. In absence of surface sensible heat flux measurements near the sea breeze front, we estimate the sensible heat flux so that $u_{s b}$ equals the measured wind speed $\left(2 \mathrm{~m} \mathrm{~s}^{-1}\right)$. This leads to $z_{s b}=450 \mathrm{~m}$, which is in agreement with the observations. Between $44^{\circ} \mathrm{N}$ and the sea breeze front (estimated to be located at about $44.5^{\circ} \mathrm{N}$ ), the sea breeze velocity increases while its depth keeps decreasing so that the ratio $z_{s b} / u_{s b}$ is no longer constant $\left(z_{s b} / u_{s b}\right.$ decreases). In this area, Bastin et al. (2005) showed that lateral constriction in the Rhône valley affects the sea breeze dynamics. On 26 June 2001 and 3 and 4 July 2001, the sea breeze vertical extent displays much less spatial variability along the Rhône valley. On 26 June 2001 and 3 July 2001, the wind speed remains approximately constant and equal to about $4 \mathrm{~m} \mathrm{~s}^{-1}$ and $3.5 \mathrm{~m} \mathrm{~s}^{-1}$ south of $44.4^{\circ} \mathrm{N}$ and $44.0^{\circ} \mathrm{N}$, respectively. North of this limit, lateral constriction by the Rhône valley sidewalls contributes to accelerating the flow. From these three cases, it appears that the ratio $z_{s b} / u_{s b}$ remains approximately constant where no lateral constriction disrupts the sea breeze flow (about 300 on 25 and 26 June 2001 and 400 on 3 July 2001). This is consistent with Green and Dalu (1980) and Steyn (1998) scaling laws assuming a constant $N$ [see Eqs. (3) and (4)]. Steyn (2003) scaling laws [see Eq. (3)] give the relationship that the air potential temperature and surface heat flux must follow if a constant ratio $z_{s b} / u_{s b}$ is to be maintained in the sea breeze flow. Indeed $z_{s b} / u_{s b}$ being constant means that $H \propto T_{0}^{-1}$ and $\hat{H} \propto T_{0}^{-1}$ in the direction perpendicular to the coast, assuming a constant $N$. In other words, close to shore, cold and moist marine air advected by the sea breeze over hot continental ground generates larger surface sensible heat fluxes than further inland where warmer air flows above hot ground generating lower surface heat flux. Concerning the aspect ratio, all the theories, except that of Dalu and Pielke (1989), tend to overpredict the aspect ratio $x_{s b} / z_{s b}$. The best scaling is that derived by Dalu and Pielke (1989) which indicates the importance of surface friction on the sea breeze shape. The major drawback of this scaling is that the damping time due to surface friction is a parameter to be adjusted. Further work needs to be done to estimate the damping time on a more physical basis.

The 4 July 2001 case is more complex, since the sea breeze development is inhibited in some areas of the Rhône valley because of a strong prevailing southerly synoptic flow which homogenizes the surface temperature pattern. However, in the region where the sea breeze blows, the predicted sea breeze depth is fairly accurately estimated using Steyn (2003) scaling law (1.4-1.5 km predicted by Steyn (2003) analysis versus $1.5 \mathrm{~km}$ measured by WIND). Using the same arguments as for the Mistral/sea breeze case, the scaling laws are not able to predict the wind speed accurately. However, one has to point out that the measured wind speed is, as a first approximation, the sum of the prevailing synoptic onshore wind and the thermally induced wind speed. Arritt (1993) suggests that onshore wind tends to weaken the crossshore temperature gradient. So, as suggested by Bastin et al. (2005), the total wind speed can be high whereas the sea breeze intensity can be weak. Table 3 suggests that the scaling laws underpredict the wind speed, but they may be accurate in predicting the contribution of the sea breeze to the total wind speed. With the available dataset, it is not possible 
to separate the two contributions. Considering the aspect ratio, the Dalu and Pielke (1989) prediction is fairly accurate $\left(x_{s b} / z_{s b}=82\right.$ versus 100 measured using WIND data). This result suggests that contrary to the offshore wind situation when two different air mass collide at the sea breeze front, the onshore wind combines with the sea breeze and thus affects less significantly the sea breeze dynamics. The onshore wind speed weakens the sea breeze by slightly decreasing the cross-shore temperature gradient, while likely increasing the sea breeze penetration, but its impact is less significant than in presence of an offshore synoptic wind (Estoque, 1962).

\section{Conclusions}

In conclusion, the deployment of the airborne Doppler lidar WIND during the ESCOMPTE field experiment contributed to mapping in three dimensions the sea breeze circulation in an unprecedented way and undoubtedly to filling gaps in our understanding of the sea breeze dynamics and related transport. The airborne Doppler lidar WIND data permit the access to the onshore and offshore sea breeze extents, and to the sea breeze depth (which proved to vary in the cross-shore direction) and intensity. They also show that the return flow of the sea breeze circulation is very seldom seen in this area, due to:

- the presence of a systematic non-zero background wind which prevails over the return flow although it is expected to be much weaker than the onshore sea breeze flow (see Fig. 2 in Rotunno, 1983),

- the 3-D structure of the sea breeze caused by the complex coastline shape and topography.

The sea breeze depth also varies horizontally. The sea breeze shape is thus far from the toroidal-circulation found in the textbooks.

The WIND data also allow a thorough analysis of the impact of the two main valleys (Rhône and Durance valleys) affecting the sea breeze circulation in the area. They show that the sea breeze is generally affected by flow splitting between the Durance and the Rhône valley whenever it reaches the bifurcation zone (which is not the case on 22 June 2001). Whenever the sea breeze flow reaches the entrance of the Durance valley (25 and 26 June 2001; 3 and 4 July 2001), the Durance valley affects the sea breeze by accelerating the sea breeze flow. In the presence of an offshore flow in the Rhône valley (22 June 2001; 25 June 2001), lateral constriction does not affect the sea breeze. On 26 June 2001, and 3 and 4 July 2001, the combination with an onshore flow leads to further penetration inland and intensification of the lowlevel southerly flow in the Durance but also in the Rhône valley. If the onshore synoptic flow is too strong, the sea breeze flow is inhibited as on 4 July 2001 in a large area in the Rhône valley. This study thus generalizes the findings by Bastin et al. (2005).
Finally, this dataset also allowed an evaluation of the existing scaling laws used to derive the sea breeze intensity, depth and horizontal extent. The main results of these studies are:

- latitude, cumulative heating and surface friction are key parameters of the sea breeze dynamics,

- in presence of strong synoptic flow, all scaling laws fail in predicting the sea breeze characteristics (the sea breeze depth however being the most accurately predicted),

- the ratio $z_{s b} / u_{s b}$ is approximately constant in the sea breeze flow which physically implies that the surface sensible heat flux scales as the inverse of the potential temperature of the air.

Acknowledgements. This work was conducted at Service d'Aéronomie and Laboratoire de Météorologie Dynamique of the Institut Pierre Simon Laplace. The authors would like to thank the two anonymous referees for their relevant comments which helped to improve the manuscript significantly; P.W. Heck for his contribution to editing the final manuscript; M.C. Lanceau for help in collecting the referenced papers; and B. Cros and P. Durand for the coordination of the experiment. The flights of the DLR Falcon was funded partly by the CAATER (Co-ordinated Access to Aircraft for Transnational Environmental Research) program of the European Commission. We also like to thank B. Romand (LMD/IPSL) and E. Nagel (DLR) for assistance in operation of the WIND system, the pilots of the DLR flight facility R. Welser and M. Hinterwaldner, the Falcon technician and the great support of the CAATER facilator A. Giez (DLR). In the framework of the French programs PNCA and PRIMEQUAL-PREDIT, ESCOMPTE was performed thanks to funding from the Ministère de l'Écologie et du Développement Durable (MEDD), the Agence de l'Environnement et de la Maitrise de l'Énergie (ADEME), the Institut National des Sciences de l'Univers (INSU), Météo-France, the Institut National de l'Environnement Industriel et des Risques (INERIS), the German funding agency (BMBF), the Institute for Meteorology and Climate Research (IMK- Karlsruhe), the Joint Research Center (JRC-Ispra), the Swiss Federal Institute of Technology (EPFL-Lausanne), the Centre National d'Études Spatiales (CNES), Électricité de France (EDF), the air quality agencies Airmaraix and Airfobep, the cities of Marseilles and Aix-en-Provence, the county council of the Bouches-du-Rhône. We are also grateful to the Société de Navigation Corse Méditerranée (SNCM) for its help and assistance with the sea measurements. We express our sincere appreciation to S. Joussaume, C. Elichegaray, for their coordination effort and support before, during and after the field experiment, and to J.P. Lacaux who solved customs clearance problems. We particularly thank M.P. Lefebvre who played a crucial role in the delicate organization of the flights, J.F. Mauro who organized the ground based sites, F. Marin our excellent scientific secretary, and all the people involved in the performing of the field campaign, whose commitment ensured the success of this operation.

Topical Editor F. D'Andrea thanks two referees for their help in evaluating this paper. 


\section{References}

Atlas, D.: Radar detection of the sea breeze, J. Meteor., 17, 244258, 1960.

Arritt, R. W.: Effects of the large-scale flow on characteristics features of the sea breeze, J. Appl. Meteor., 32, 116-125, 1993.

Baines, P. G.: Observations of stratified flow past a threedimensional barrier, J. Geophys. Res., 84, 7834-7838, 1979.

Banta, R. M., Olivier, L. D., and Levinson, D. H.: Evolution of the Monterey Bay sea breeze layer as observed by pulsed Doppler lidar, J. Atmos. Sci., 50, 3959-3982, 1993.

Banta, R. M.: Sea breezes shallow, and deep on the California coast, Mon. Wea. Rev., 123, 3614-3622, 1995.

Bastin, S., Drobinski, P., Dabas, A. M., Delville, P., Reitebuch, O., and Werner, C.: Impact of the Rhône, and Durance valleys on sea breeze circulation in the Marseille area, Atmos. Res., 74, 303328, 2005.

Bastin, S., Drobinski, P., Guénard, V., Caccia, J. L., Campistron, B., Dabas, A. M., Delville, P., Reitebuch, O., and Werner, C.: On the interaction between sea breeze, and summer mistral at the exit of the Rhône valley, Mon. Wea. Rev., 134, 1647-1668, 2006.

Bastin, S. and Drobinski, P.: Temperature, and wind velocity oscillations along a gentle slope during sea breeze events, Bound.Layer Meteorol., 114, 573-594, 2005.

Bastin, S. and Drobinski, P.: Sea breeze induced mass transport over complex terrain in southeastern France: a case study, Quart. J. Roy. Meteorol. Soc., 132, 405-423, 2006.

Browning, R. A. and Wexler, R.: The determination of kinematic properties of a wind field using Doppler radar, J. Appl. Meteorol., 7, 105-113, 1968.

Burton, B. J.: Passage of a well marked sea breeze front at Wokingham, Weather, 55, 281-286, 2000.

Caroll, J. J.: Analysis of airborne Doppler lidar measurements of the extended California sea breeze, J. Atmos. Oceanic Technol., 6, 820-831, 1989.

Caya, D. and Zawadzki, I.: VAD analysis of nonlinear wind fields, J. Atmos. Oceanic Technol., 9, 575-587, 1992.

Corsmeier, U., Behrendt, R., Drobinski, P.,and Kottmeier, C.: The Mistral and its effect on air pollution transport and vertical mixing, Atmos. Res., 74, 275-302, 2005.

Cros, B., Durand, P., Cachier, H., Drobinski, P., Frejafon, E., Kottmeier, C., Perros, P. E., Peuch, V. H., Ponche, J. L., Robin, D., Said, F., Toupance, G., and Wortham, H.: The ESCOMPTE program: an overview, Atmos. Res., 69, 241-279, 2004.

Dabas, A., Drobinski, P., and Flamant, P. H.: Adaptive filters for frequency estimate of heterodyne Doppler lidar returns: recursive implementation, and quality control, J. Atmos. Oceanic Technol., 16, 361-372, 1999.

Dalu, G. A. and Pielke, R. A.: An analytical study of the sea breeze, J. Atmos. Sci., 46, 1815-1825, 1989.

Dalu, G. A. and Pielke, J. S. A.: Energetics of diabatic mesoscale circulation: a numerical study, Quart. J. Roy. Meteorol. Soc., 106, 727-734, 1980.

Darby, L. S., Banta, R. M., and Pielke, R. A.: Comparisons between mesoscale model terrain sensitivity studies, and Doppler lidar measurements of the sea breeze at Monterey Bay, Mon. Wea. Rev., 130, 2813-2838, 2002.

Drobinski, P., Bastin, S., Guénard, V., Caccia, J. L., Dabas, A. M., Delville, P., Protat, A., Reitebuch, O., and Werner, C.: Summer Mistral at the exit of the Rhône valley, Quart. J. Roy. Meteorol.
Soc., 131, 353-375, 2005.

Drobinski, P., Dusek, J., and Flamant, C.: Diagnostics of hydraulic jump and gap flow in stratified flows over topography, Bound.Layer Meteor., 98, 475-495, 2001.

Estoque, M. A.: The sea breeze as a function of the prevailing synoptic situation, J. Atmos. Sci., 19, 244-250, 1962.

Feliks, Y.: An analytical model of the diurnal oscillation of the inversion base due to the sea-breeze, J. Atmos. Sci., 51, 991-998, 1963.

Feliks, Y.: A numerical model for estimation of the diurnal fluctuation of the inversion height due to a sea-breeze, Bound.-Layer Meteorol., 62, 151-161, 1993.

Finkele, K., Hacker, J. M., Kraus, H., and Byron-Scott, R. A. D.: A complete sea breeze circulation cell derived from aircraft observations, Bound.-Layer Meteor., 73, 299-317, 1995.

Green, J. S. A. and Dalu, G. A.: Mesoscale energy generated in the boundary layer, Quart. J. Roy. Meteorol. Soc., 106, 721-726, 1980.

Hadi, T. W., Horinouchi, T., Tsuda, T., Hashiguchi, H., and Fukao, S.: Sea-breeze circulation over Jakarta, Indonesia: A climatology based on boundary layer radar observations, Mon. Wea. Rev., 130, 2153-2166, 2002.

Holland, G. J. and McBride, J. L.: Quasi-trajectory analysis of a sea breeze front, Quart. J. Roy. Meteor. Soc., 115, 571-580, 1989.

Keen, C. S. and Lyons, W. A.: Lake/land breeze circulations on the western shore of lake Michigan, J. Appl. Meteorol., 17, 1843$1855,1978$.

Lee, O. S. M. and Shun, C. M.: Observation of sea breeze interactions at and near Hong Kong International Airport, Meteorol. Appl., 10, 1-9, 2003.

Lemonsu, A., Bastin, S., Masson, V., and Drobinski, P.: Vertical structure of the urban boundary layer over Marseille under sea breeze conditions, Bound.-Layer Meteorol., in press, 2006.

Lyons, W. A.: The climatology, and prediction of the Chicago lake breeze, J. Appl. Meteor., 11, 1259-1270, 1972.

Niino, H.: The linear theory of land, and sea breeze circulation, J. Meteor. Soc. Japan, 65, 901-920, 1987.

Mahrer, Y. and Pielke, R. A.: A test of an upstream spline interpolation technique for the advective terms in a numerical mesoscale model, Mon. Wea. Rev., 106, 818-830, 1978.

Manins, P. C. and Sawford, B. L.: Mesoscale observations of upstream blocking, Q. J. R. Meteorol. Soc., 108, 427-434, 1982.

Mestayer, P., Durand, P., Augustin, P., Bastin, S., Bonnefond, J. M., Bénech, B., Campistron, B., Coppalle, A., Delbarre, H., Dousset, B., Drobinski, P., Druilhet, A., Fréjafon, E., Grimmond, S., Groleau, D., Irvine, M., Kergomard, C., Kermadi, S., Lagouarde, J. P., Lemonsu, A., Lohou, F., Long, N., Masson, V., Moppert, C., Noilhan, J., Offerle, B., Oke, T., Pigeon, G., Puygrenier, V., Roberts, S., Rosant, J.M., Saïd, F., Salmond, J., Talbaut, M., and Voogt, J.: The urban boundary layer field experiment over Marseille UBL/CLU-ESCOMPTE: experimental set-up and first results, Bound.-Layer Meteorol., 114, 315-365, 2005.

Moorthy, K. K., Pillai, P. S., and Babu, S. S.: Influence of changes in the prevailing synoptic conditions on the response of aerosol characteristics to land-, and sea breeze circulations at a coastal station, Bound.-Layer Meteorol., 108, 145-161, 2003.

Reitebuch, O., Werner, C., Leike, I., Delville, P., Flamant, P. H., Cress, A., and Engelbart, D.: Experimental validation of wind profiling performed by the airborne $10.6 \mu \mathrm{m}$-heterodyne Doppler 
lidar WIND, J. Atmos. Oceanic Technol., 18, 1331-1344, 2001. Reitebuch, O., Volkert, H., Werner, C., Dabas, A., Delville, P., Drobinski, P., Flamant, P. H., and Richard, E.: Determination of airflow across the Alpine Ridge by a combination of Doppler lidar, routine radiosounding, and numerical simulation, Quart. J. Roy. Meteor. Soc., 129, 715-727, 2003.

Rotunno, R.: On the linear theory of the land, and sea breeze, J. Atmos. Sci., 40, 1999-2009, 1983.

Simpson, J. E: Sea breeze, and local winds, Cambridge University Press, U.K., 234, 1994.
Steyn, D. G.: Scaling the vertical structure of sea breezes revisited, Bound.-Layer Meteorol., 107, 177-188, 2003.

Steyn, D. G.: Scaling the vertical structure of sea breezes, Bound.Layer Meteorol., 86, 505-524, 1998.

Walsh, J. E.: Sea-breeze theory and applications, J. Atmos Sci., 31, 2012-2026, 1974.

Werner, C., Flamant, P. H., Reitebuch, O., Köpp, F., Streicher, J., Rahm, S., Nagel, E., Klier, M., Herrmann, H., Loth, C., Delville, P., Drobinski, P., Romand, B., Boitel, C., Oh, D., Lopez, M., Meissonnier, M., Bruneau, D., and Dabas, A. M.: WIND instrument, Opt. Eng., 40, 115-125, 2001. 